\section{Biotech companies rescue Italian vaccine institute}

Munich. One of Italy's most renowned research institutes, on the brink of closing in 1990 , has a new owner, a new name and a new mission.

The Sclavo Research Institute in Siena was purchased earlier this year by Biocine, a California company set up in 1986 as a joint venture between Ciba-Geigy and Chiron. The two companies paid 77,000 million lira (US\$62 million) to preserve the world-class vaccine research group at the institute, whose name now is the Immunobiological Research Institute Siena (IRIS).

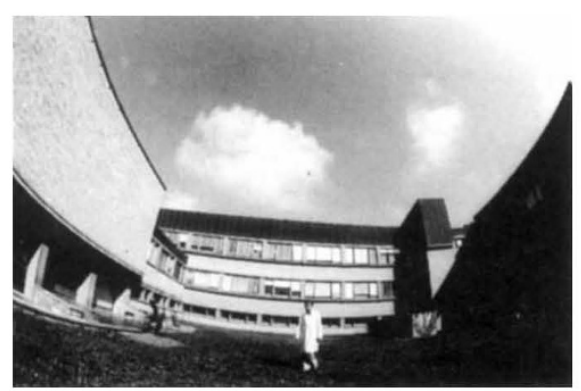

The proud tradition of the Sclavo Research Institute carries on with a new name.

The companies view the acquisition as a quick way into the paediatric vaccine market. They are streamlining IRIS's research operations and intend to focus exclusively on vaccine development. They have already announced plans to fill 30 new academic posts.

The Sclavo institute was set up by Achille Sclavo, professor of hygiene at the University of Siena, who in 1904 made a serum against anthrax in his cellar. As a privately owned company, Sclavo grew eventually to 1,500 employees, including 100 scientists. It became world famous for its development of the pertussis toxin (whooping cough) vaccine.

But the institute fell on hard times in the mid-1970s, as public confidence in vaccines was shaken after claims of serious side effects, particularly neurotoxicity. The world vaccine market collapsed and Sclavo was taken over by the state-owned company Enichem to protect Italy's source of sera and vaccines. In the early $1980 \mathrm{~s}$, Sclavo became one of Italy's first centres for biotechnology, with the Italian government paying almost half of its annual budget of 15,000 million lira.

But by 1990 the company was in trouble again, reporting a loss of 20,000 million lira in the first six months of that year. Enichem was sold to the Italian pharmaceutical and broadcast group Marcucci, which decided to discontinue its commitment to biological research (see Nature 346, 497; 1990).

Responding to national and international pressure to save the centre, the Italian government stepped in once more. Research minister Antonio Roberti blocked moves by Marcucci to dismiss researchers and guaranteed payment of about 60 per cent of the centre's annual operating budget. In exchange, the government is believed to have considered more leniently the company's requests to lay off more than 300 workers at other plants. (The government pays 80 per cent of the wages of those who are laid off.)

Biocine was set up to combine Chiron's expertise in genetic engineering and CibaGeigy's experience in immunostimulatory molecules. The improved safety of recently developed genetically engineered vaccines has restored confidence in vaccination programmes for children in the eyes of the public, and Chiron officials believe that the acquisition of Sclavo will give them an established entry into the burgeoning paediatric vaccine market. They have also promised to maintain the institute's tradition of basic research in immunology.

Dino Dina, vice-president of Chiron's vaccine programme, says that Sclavo was an attractive opportunity despite the company's poor commercial performance under Enichem. "There are a lot of excellent people in the labs, it was set up with state-ofthe-art technology for producing recombinant vaccines and it has a manufacturing capacity that is crucial to our programme", he said. The plans to restructure the company include dropping projects, such as inflammation pharmacology, that do not relate directly to vaccine development. Dina is confident that this strategy, combined with the initial investment - the 30 new academic posts are being established immediately - will help IRIS through its current problems.

Two new products are expected to be marketed by IRIS by the end of this year. One is a vaccine against Hemophilus influenza $B$, a virus responsible for about 40 per cent of the meningitis cases in Italy. The second is a vaccine against recombinant pertussis toxin, which will replace the current whooping cough vaccine, produced from whole cell cultures, whose association with neurological damage has limited its general acceptance. The institute's director, Rino Rappuoli, was last year awarded the Paul Ehrlich prize for his work on this vaccine. IRIS is also developing vaccines against Helobacter pilori, a bacteria associated with gastric ulcers and tumours, papilloma virus and cholera.

Alison Abbott

\section{Archaeopteryx fossil disappears from private collection}

Munich. Palaeontologists in Germany are trying to unravel the mystery behind the disappearance of one of the world's most important fossils.

One of only six identified specimens of Archaeopteryx lithographica, all of which have been discovered in quarries in the Solnhofen area of Bavaria, has been missing since the suicide of its finder and owner, Eduard Opitsch, in February 1991 at the age of 91 . The incident has once again demonstrated the vulnerability and inaccessibility of privately owned fossils.

Archaeopteryx is particularly important to evolutionary biologists because it is the most primitive bird known. It provides the major evidence in the theory that birds have evolved from reptiles.

The Maxberg specimen, so-called because it was exhibited in the Maxberg Museum near Solnhofen after its discovery in 1956, was removed from public display by Opitsch in 1974. Since then Opitsch, known locally as an eccentric, has not allowed any access to the scientifically vital fossil.

After the death of Optisch, who owned and operated a quarry in the area, his relatives could find no trace of the two limestone slabs (one approximately $50 \mathrm{~cm}$ by $35 \mathrm{~cm}$, and the second 40 by $35 \mathrm{~cm}$, and each slab 12 to $15 \mathrm{~mm}$ thick) that contain the fossil. Peter Wellnhofer, of the Bavarian Palaentological Museum in Munich, fears that the fossil may be put up for sale on the black market. "We want the scientific community to be on the lookout for this specimen", he says. Anyone learning of its whereabouts, he says, "should be cautious, but inform either us or the police".

Items of natural heritage, as opposed to works of art, are generally not well controlled in Europe. Although the neighbouring state of Baden-Württenberg has strictly enforced laws against the movement of cultural possessions across its boundaries, $\mathrm{Ba}$ varia has no similarly protective laws.

Although the Maxberg Archaeopteryx is a relatively fragmented specimen, its scientific and monetary value is high. The best preserved specimen, housed in London's Natural History Museum, has been valued at around $£ 2-3$ million (US $\$ 3.5-5$ million). But Angela Milner, head of the museum's section on fossil amphibians, reptiles and birds, says that a monetary value is meaningless. "There are so few specimens of Archaeopteryx that this scientific loss is just extremely sad".

Alison Abbott

Anyone with information about the fossil should contact $P$. Wellnhofer at Bayrische Staatssammlung for Paläontologie und historische Geologie, Richard-Wagner-Str. 10, 8000 Munich 2, Germany; or the police at Staatsanwaltschaft Munich 2, Germany; or the police at Staatsanwaltsch
Ansbach, Promenade 4, 8800 Ansbach, Germany. 